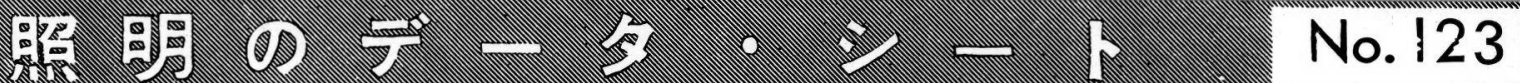

\section{日立製作所 習志野工場 (千葉県) の照明}

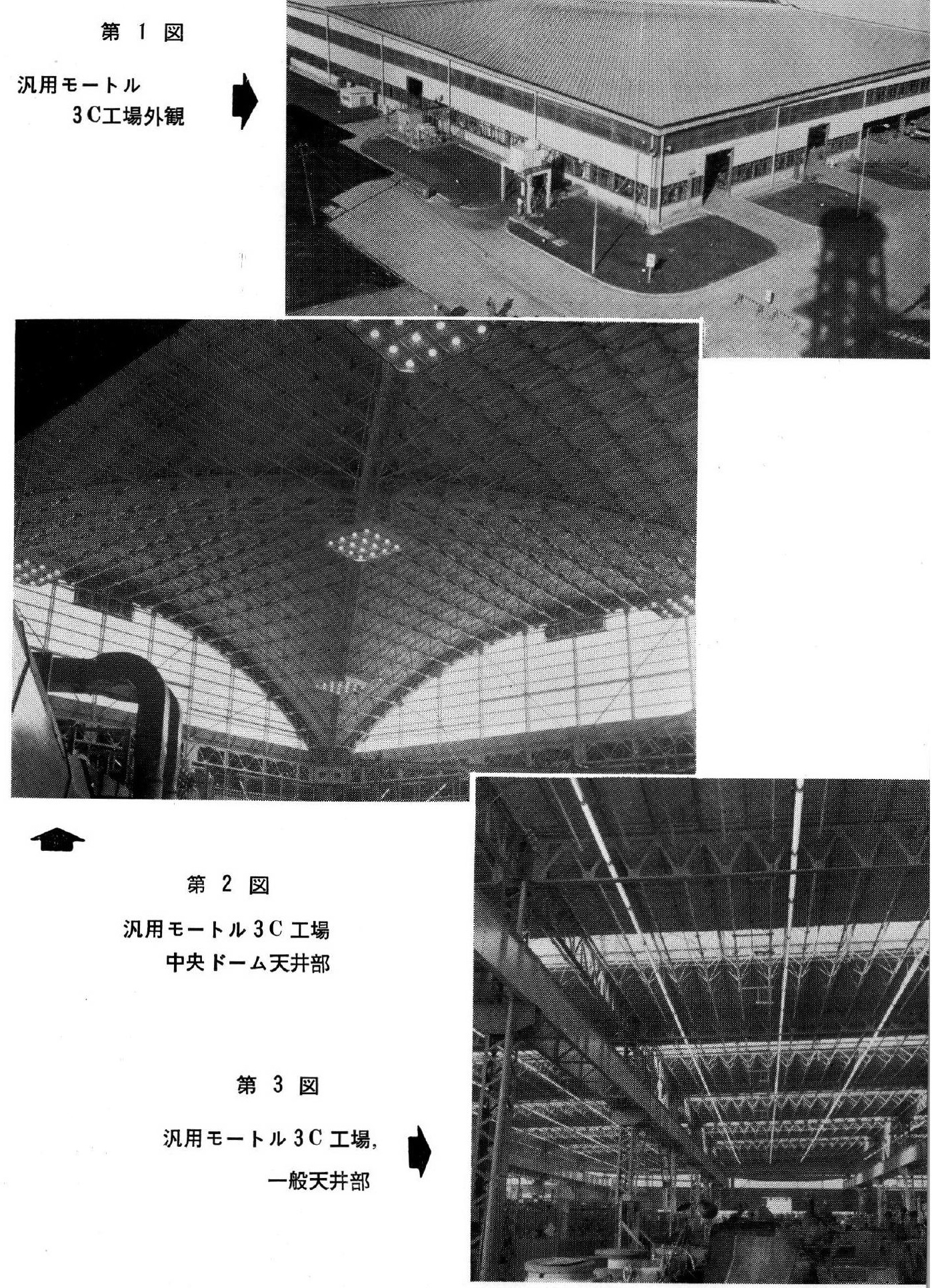




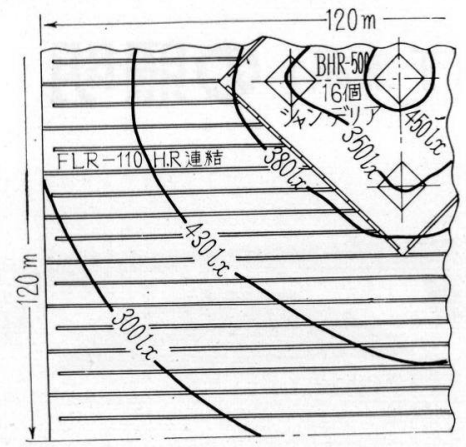

\section{第 4 図 照明器具配置および 等照度曲線}

\section{概 要}

本年 4 月に完成した日立製作所の習志野工場は，敷地 約 $49.5 \mathrm{~km}^{2}$, 建坪は現在のところ約 $25 \mathrm{~km}^{2}$ である. 今回 紹介する汎用モートル工場はその一部で, 中央にドーム 状の高天井を有して招り，一種独特の近代的な構造であ る.

照明は，生産性向上さらに作業環境の合理化をはかる よう光源をコンベア流れと平行に, $110 \mathrm{~W}$ 高出力けい光 ランプを採用，ラインライティング方式によるきわめて ざん新なものである。

また中央ドーム状高天井部分にはバラストレス水銀ラ ンプを使用している（第 1，2，3図参照）.

建物面積 $\quad 120 \mathrm{~m} \times 120 \mathrm{~m}$

天井高さ 平均 $8 \mathrm{~m}$ 中央ドーム状天井高さ

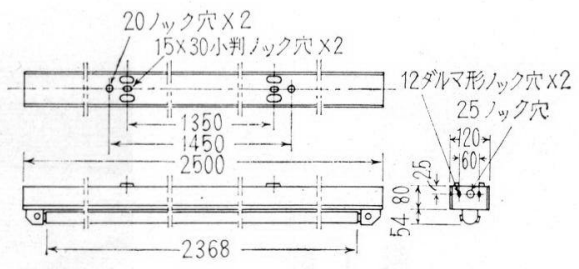

\section{—第 5 図 けい光灯器具寸法図 (PM11103 LS)}

\section{光 源}

普通天井には，配光方向が自由に変えることのできる $110 \mathrm{~W}$ 反射形白色けい光ランプが， $3.75 \mathrm{~m}$ 間隔にライン ライティング方式で使われて批り，中央ドーム状高天井 には $110 \mathrm{~W}$ けい光ランプの使用は不可能であるので演 色性走考虑し，天井 5 カ所からつり下げる $500 \mathrm{~W}$ バラス トレス水銀ランプが，シャンデリア方式で使われてい る(第 2, 3 図 参照).

\section{使用器具数量}

普通天井 $110 \mathrm{~W} 1$ 灯用器具 (第 5 図参照) 1, 200台 ドーム状高天井 500Wバラストレス水銀ランプ 80個 照 度

汎用モートル工場は床上 $0.8 \mathrm{~m}$ 水平面に扎ける平均照 度3501xである（第 4 図参照）。

$\begin{array}{ll}\text { 施 主 } & \text { (株) 日立製作所 } \\ \text { 設 計 } & \text { 日 建 設 計 (株) } \\ \text { 電気工事 } & \text { 本 城 工 業 (株) } \\ \text { 照明器具設計製作 (株) 日立製作所 }\end{array}$




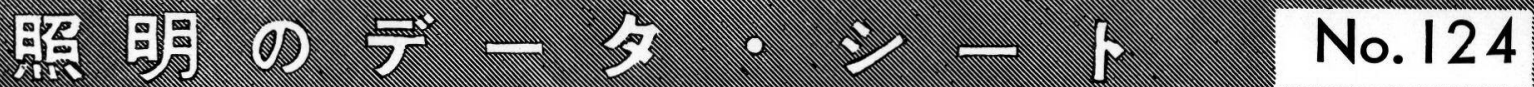

札幌市・大通公園の噴 水照明

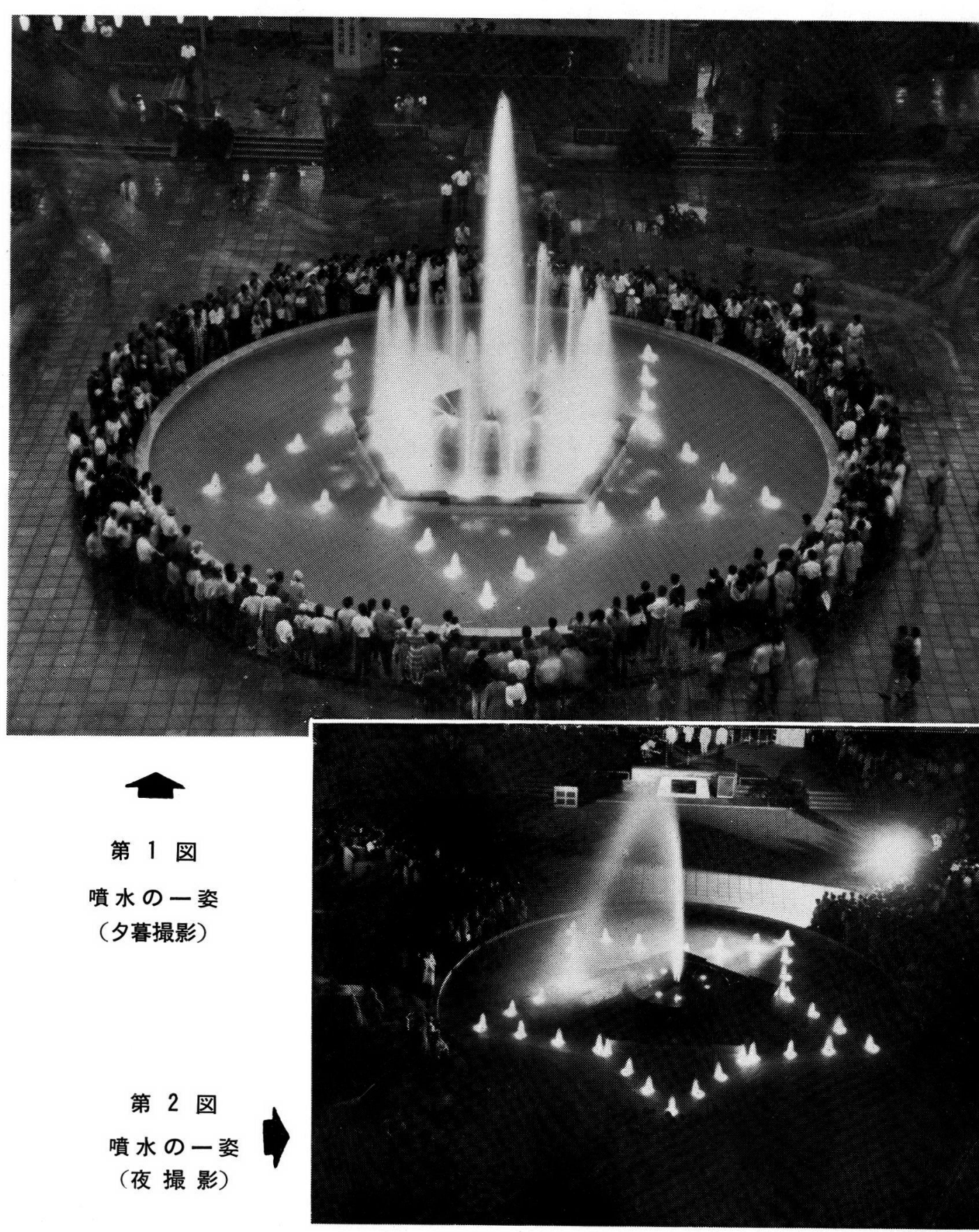




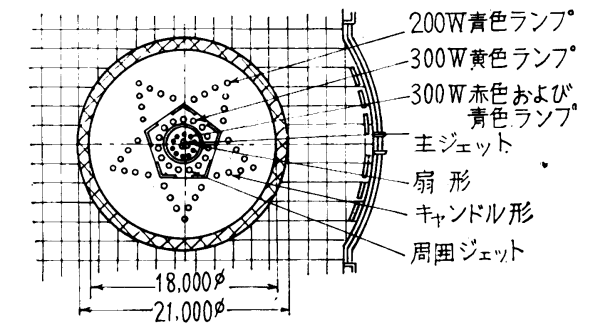

第 3 図置 配 図

\section{概 要}

札幌市の新名所，大通公園にこの ほど大噴水が完成した。中央に 3 本 のシェット形噴水，そのすぐまわり に，10本の放射扇形の䠝水が配置さ れ，さらにそのまわりには15本の円 筒形シェット形噴水があり，いちば ん外側に35本のキャンドル形噴水が 星状に並んでいる(第 3 図参照).

噴水の高さは中央のジェット形が $6 \mathrm{~m}$, 円筒形シェット形が $3 \mathrm{~m}$, 放 射扇形噴水は高さ $1.2 \mathrm{~m}$, 到達距離 $3.5 \mathrm{~m}$ である。 また星状キャンドル 形噴水は高さ $0.4 \mathrm{~m}$ である.

これらの噴水は 1 周期 3 分ごとに 自動的に 6 種の形状に変化し，これ に合わせ照明も変化する（第 4 図参 第 4 図照).

噴水変化図中央の噴水は赤, 青, 黄 3 色が10 秒ごとに色彩を変え, 円筒形噴水は 黄色, まわりのキャンドル形噴水は青色にいずれも水中 照明が行なわれている（第 1，2図参照）。

機械設備は中央ジェッ卜噴水用, 扇形用, 円简形ジェ

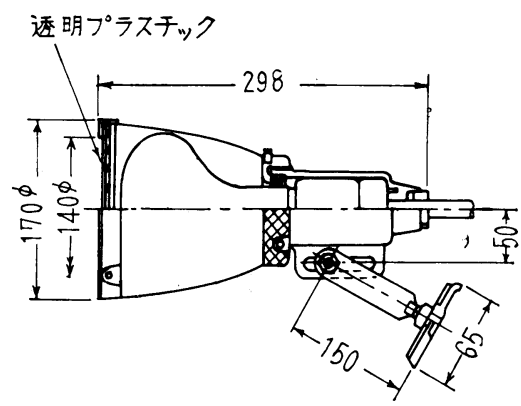

第 5 図 灯具寸法図

ット噴水用, 星形キャンドル噴水用のポンプ 3 台のほ か, 各ポンプ用電動機が設備されている.

\section{使用光源および数量}

$\bigcirc$ 中央噴水照明用 300W反射形赤色白熱ランプ 3 個 300W反射形黄色白熱ランナ゚ 3 個 300W反射形青色白熱ランプ 3 個

円筒形噴水照明用 300W反射形黄色白熱ランナ゚ 15個

○星状噴水照明用 200W反射形青色白熱ランプ 35個

\section{使用照明器具および数量}

水中形ホルダー（第 5 図参照）

\section{照明器具配置第 3 図のと扔り}

施主札幌市役所

噴 水設計, 施工 (株)日立製作所 照明器具設計, 製作 (株)日立製作所 